\title{
MANCHESTER
}

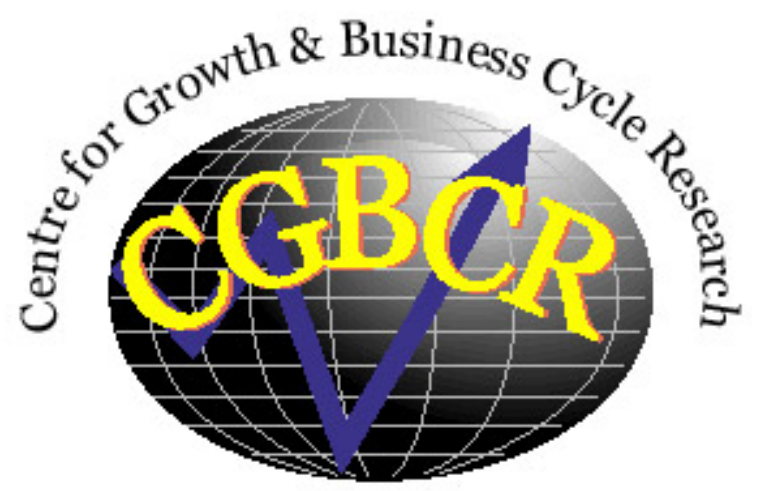

Discussion Paper Series

\section{Excess Liquidity, Bank Pricing Rules, and Monetary Policy \\ By}

\section{Pierre-Richard Agénor and Karim El Aynaoui}

Centre for Growth and Business Cycle Research, Economic Studies,

University of Manchester, Manchester, M13 9PL, UK

September 2008

Number 105

Download paper from:

http://www.ses.man.ac.uk/cgbcr/discussi.htm 


\title{
Excess Liquidity, Bank Pricing Rules, and Monetary Policy
}

\author{
Pierre-Richard Agénor* and Karim El Aynaoui** \\ First complete draft: March 25, 2008 \\ This version: September 9, 2008
}

\begin{abstract}
This paper analyzes the implications of excess bank liquidity for the effectiveness of monetary policy in a simple model with credit market imperfections. Lending rates are set as a premium over the cost of borrowing from the central bank, with the premium itself depending on firms' net worth. The demand for excess reserves is determined by precautionary factors and opportunity cost variables. The basic framework is used to examine the impact of a change in the refinance rate and the required reserve ratio. The analysis is then extended to account for the impact of excess liquidity on bank pricing rules and macroeconomic equilibrium. Symmetric and asymmetric rules are shown to provide new explanations of the "price puzzle" or "stagflationary" effect associated with contractionary monetary policy.
\end{abstract}

JEL Classification Numbers: E44, E51, F41.

${ }^{*}$ Hallsworth Professor of International Macroeconomics and Development Economics, University of Manchester, United Kingdom, and Centre for Growth and Business Cycle Research; ${ }^{* *}$ Director of Research, Central Bank of Morocco. We are grateful to Koray Alper and Peter Montiel for many helpful comments on a previous draft. The views expressed in this paper are our own. 


\section{Contents}

1 Introduction 3

2 The Basic Framework 6

2.1 Supply side and Prices . . . . . . . . . . . . . . 7

2.2 Households . . . . . . . . . . . . . . . . . 9

2.3 Commercial Bank . . . . . . . . . . . . . . 10

2.3.1 Interest Rate Pricing Rules . . . . . . . . . . . . . . . 11

2.3.2 Demand for Excess Reserves . . . . . . . . . . . . 13

2.3.3 Borrowing from Central Bank . . . . . . . . . . . 14

2.4 Central Bank and Government . . . . . . . . . . . . . . . . 15

2.5 Investment and Goods Market . . . . . . . . . . . . 15

3 Model Solution $\quad 16$

4 Impact of Monetary Policy $\quad 20$

5 Excess Liquidity and Pricing Behavior 22

5.1 Deposit Rates . . . . . . . . . . . . . . . . . . 23

5.2 Risk Premium and Lending Rates . . . . . . . . . . . . 28

6 Concluding Remarks $\quad 30$

$\begin{array}{ll}\text { References } & 34\end{array}$

$\begin{array}{ll}\text { Figure 1. Macroeconomic Equilibrium } & 36\end{array}$

Figure 2. Increase in the Required Reserve Ratio 37

Figure 3. Increase in the Refinance Rate 38 


\section{Introduction}

A recurrent concern of central bankers is the possibility that an abundance of liquidity may hamper the ability of monetary policy to influence the level of economic activity and inflation. For most financial systems, excess liquidity can be defined as the involuntary accumulation of liquid reserves by commercial banks. ${ }^{1}$ Thus, although banks may choose to hold reserves above and beyond what is required by the legislation (to satisfy unexpected withdrawals for cash from their clients, for instance, or because of an increase in volatility), excess liquidity prevails only if they unwillingly hold more cash than desired. In a highly volatile or crisis environment, for instance, the demand for reserves may increase sharply for "precautionary" reasons, because banks find it too risky to lend. This observation, as argued by Agénor, Aizenman, and Hoffmaister (2004), provides a useful starting point for a methodology aimed at identifying the source of a credit crunch: if banks are unwilling, rather than unable, to extend loans, a contraction in credit can be attributed to supply, rather than demand, factors. The first step to perform this test is therefore to estimate a demand function for excess liquid assets by commercial banks and then examine its predictive capacity.

From an analytical standpoint, it is convenient to classify the factors leading to excess liquidity into structural and cyclical factors. The first structural factor that is commonly identified is a low degree of financial development. In countries with less developed financial systems banks will tend to have a greater demand for excess liquidity. This is one of the main explanation of the high and persistent levels of bank reserves (above and beyond those

\footnotetext{
${ }^{1} \mathrm{~A}$ more comprehensive measure of excess liquidity may be warranted for some countries, to account for banks' holdings of short-term government securities; see Mohanti, Schnabel, and Garcia-Lima (2006).
} 
required by the law) in the low-income countries of Central Africa, where opportunities for portfolio allocation are limited (see Saxegaard (2006)). A second factor is a high degree of risk aversion, which leads to high risk premia and a low demand for credit. The degree of risk aversion, in turn, may be directly related to chronic macroeconomic instability, and this may explain a positive correlation between high inflation and excess liquidity.

Inflation may also represent a cyclical cause of excess liquidity. To the extent that it is accompanied by higher volatility in relative prices (and thus an increase in the riskiness of investment projects), a surge in inflation may raise uncertainty about the value of collateral - leading banks to either charge a higher risk premium or increase the incidence of credit rationing (in the presence of adverse selection problems). Because, in the former case, a higher lending rate may lead to a contraction in credit demand, both responses may translate into an involuntarily accumulation of excess reserves.

Another important cyclical factor is large capital inflows, which may be related to greater capital liberalization. In recent years, a number of countries, low- and middle-income alike, have indeed implemented measures to foster an asymmetric opening of the capital account (that is, with a lifting of restrictions on capital movements for non-residents) and have faced large capital inflows, often associated with privatization of large-scale state enterprises. In Guyana for instance, excess reserves have increased dramatically since the late 1990s (see Khemraj (2007)). In Morocco, a number of large privatization operations and increased amounts of foreign direct investment have also led in recent years to a sharp increase in liquidity in the banking system, leading the central bank to increase sharply reserve requirements to avoid the development of inflationary pressures (see Agénor and El Aynaoui (2007)). 
Surprisingly enough, and despite the importance of the issue for central banks, there have been few attempts to explore analytically the implications of excess liquidity for the effectiveness of monetary policy. ${ }^{2}$ This paper attempts to bridge this gap by proposing a simple macroeconomic model where banks' pricing behavior and portfolio decisions are explicitly accounted for. Given the static nature of our framework, we do not specifically identify the source (structural or cyclical) of excess liquidity; instead, we focus on the case where the (voluntary) motive for holding excess reserves is uncertainty about cash withdrawals by the public, and define excess liquidity as a situation where actual excess reserves exceed the desired value. Although our framework is fairly general, the countries that we have in mind are middleincome countries where the financial system is sufficiently developed to allow monetary policy to operate through the manipulation of a short-term interest rate whose "pass-through" effect on market rates is rapid, just like in more developed countries; in many low-income countries, by contrast, monetary policy is often based on indirect instruments. At the same time, however, we assume that the financial system is dominated by banks and that capital markets are either underdeveloped or illiquid - in line with the evidence for middle-income countries. Thus, firms in these countries (unlike their counterparts in more developed countries) have no real alternative but to either use retained earnings or borrow from commercial banks if they must cover production costs prior to the sale of output. ${ }^{3}$

\footnotetext{
${ }^{2}$ Dwelling on the analytical framework in Agénor, Aizenman, and Hoffmaister (2004), Saxegaard (2006) studies empirically the determinants of excess reserves. However, the analysis remains fundamentally partial equilibrium in nature.

${ }^{3}$ A third characteristic that differentiates middle-income and more developed countries is the degree of capital mobility, which remains largely imperfect for the first group (see Agénor and Montiel (2008b)). However, in the present case this does not carry any specific implication, given that we consider only a closed economy.
} 
The rest of the paper is organized as follows. Section II presents the model, which dwells on the framework for short-run monetary policy analysis developed in Agénor and Montiel (2006, 2008a). Because open-economy considerations are somewhat tangential to the issue at hand, we deliberately simplify their approach by focusing on a closed economy. As in these original contributions, credit market imperfections are introduced by assuming that commercial banks set both deposit and lending rates, in the latter case as a premium over the cost of borrowing from the central bank. The premium itself depends on firms' net worth, in the tradition of Bernanke and Gertler (1989). In addition, however, we also derive explicitly a demand function for excess reserves. In Section III, the basic framework is used to examine the financial and real effects of a change in the official cost of borrowing and the required reserve ratio. The analysis is then extended in Section IV to introduce an asymmetric effect of excess liquidity on bank pricing rules and determine how these asymmetries affect the effectiveness of monetary policy. This section represents the essential contribution of this paper; it has been argued before that excess liquidity may generate asymmetric pricing behavior, but (as far as we know) this has not been formally analyzed before. The last section offers some concluding remarks and suggests some directions for future research.

\section{The Basic Framework}

Consider a closed economy producing a single, homogeneous good. There are five markets in the economy (for currency, bank deposits, credit, bonds, and goods), and five categories of agents: firms, households, a commercial bank (or bank, for short), the government, and the central bank. 


\subsection{Supply side and Prices}

To finance their working capital needs, which consist solely of labor costs, firms (which have no retained earnings, for simplicity) must borrow from the bank. ${ }^{4}$ Total production costs faced by the representative firm are thus equal to the wage bill plus the interest payments made on bank loans. ${ }^{5}$ For simplicity, we will assume that loans contracted for the purpose of financing working capital (which are short-term in nature), are made at a fixed markup (normalized to unity) over the cost of borrowing from the central bank, at the rate $i_{R} \cdot{ }^{6}$ Firms repay loans, with interest, at the end of the period, after goods have been produced and sold. Hence, loans are supplied and repaid within a period and are not accumulated. Profits are transferred at the end of each period to the firms' owners, households.

Formally, the maximization problem faced by the representative firm can be written as

$$
\max _{y} P Y-W \cdot N-i_{R} L^{F},
$$

where $Y$ denotes output, $P$ the price of the good, $W$ the nominal wage, $N$ the quantity of labor employed, $i_{R}$ the official rate charged by the central bank to the commercial bank (or the refinance rate, for short), and $L^{F}$ the

\footnotetext{
${ }^{4}$ There is no substitute for bank loans, so that firms cannot issue equities or bonds (claims on their capital stock) to finance their working capital needs. In addition, given our assumption of a closed economy, firms have no direct access to world capital markets.

${ }^{5}$ The direct effect of lending rates on firms' marginal production costs is a common feature of developing economies, and there is evidence that it may be important also in industrial countries. See for instance Ravenna and Walsh (2006) for the United States, and Gaiotti and Secchi (2006) for Italy. The link between credit, working capital needs, and output was emphasized early on in the New Structuralist literature by Taylor (1983) and van Wijnbergen (1982) and is the foundation of the so-called Cavallo-Patman effect.

${ }^{6}$ While this approach focuses on the costs of external funds, the logic of interest rate effects on firms' costs also applies when firms are primarily financed by internal funds (see Barth and Ramey (2001)). Thus, direct cost effects of interest rates are not particular to economies with a high ratio of external to internal funds.
} 
nominal amount of loans allocated by the bank.

The production function takes the form

$$
Y=N^{\alpha} K_{0}^{1-\alpha}
$$

where $K_{0}$ is the beginning-of-period stock of physical capital (which is therefore predetermined), and $\alpha \in(0,1)$. The firm's financial constraint is given by

$$
L^{F} \geq W \cdot N+P \cdot I
$$

where $I$ denotes real private investment. Constraint (3) will be assumed to be continuously binding, because the only reason for firms to demand loans is to finance labor costs and capital accumulation.

Maximizing equation (1) subject to (2), taking $i_{R}$ and $I$ as given, yields the first-order condition

$$
\alpha P N^{\alpha-1} K_{0}^{1-\alpha}-\left(1+i_{R}\right) W=0 .
$$

This condition yields labor demand as

$$
N^{d}=\left[\frac{\alpha K_{0}^{1-\alpha}}{\left(1+i_{R}\right)(W / P)}\right]^{1 /(1-\alpha)},
$$

which can be substituted in (2) to give

$$
Y^{s} \equiv\left[\frac{\alpha}{\left(1+i_{R}\right)(W / P)}\right]^{\alpha /(1-\alpha)} K_{0}
$$

These equations show that labor demand and supply of the good are inversely related to the effective cost of labor, $\left(1+i_{R}\right)(W / P)$.

Given the short-run nature of the model, the nominal wage is assumed to be rigid at $\bar{W} \cdot{ }^{7}$ This implies, from (4) and (5), that

$$
N^{d}=N^{d}\left(P ; i_{R}\right), \quad Y^{s}=Y^{s}\left(P ; i_{R}\right)
$$

\footnotetext{
${ }^{7}$ Assuming less-than-perfect indexation would not alter qualitatively our results.
} 
with $N_{1}^{d}, Y_{1}^{s}>0$, and $N_{2}^{d}, Y_{2}^{s}<0 .{ }^{8}$ An increase in borrowing costs or a reduction in prices (which raises the real wage) exert a contractionary effect on output and employment.

Using equations (3) and (6), firms' total demand for credit is given by

$$
L^{F}=\bar{W} N^{d}\left(P ; i_{R}\right)+P I
$$

\subsection{Households}

Households supply labor inelastically, consume goods, and hold two categories of imperfectly substitutable assets: currency (which bears no interest), in nominal quantity $B I L L$, and bank deposits, in nominal quantity $D .{ }^{9}$ Household wealth, $A^{H}$, is thus defined as:

$$
A^{H}=B I L L+D
$$

The relative demand for deposits is assumed to be positively related to its rate of return:

$$
\frac{D}{B I L L}=\nu\left(i_{D}\right)
$$

where $i_{D}$ is the interest rate on bank deposits and $\nu^{\prime}>0$. Combining these two equations yields

$$
D=\frac{\nu\left(i_{D}\right)}{1+\nu\left(i_{D}\right)} A^{H}=\kappa\left(i_{D}\right) A^{H}
$$

where $\kappa^{\prime}>0$.

\footnotetext{
${ }^{8}$ Except otherwise indicated, partial derivatives are denoted by corresponding subscripts, whereas the total derivative of a function of a single argument is denoted by a prime.

${ }^{9}$ As in Agénor and Montiel (2006, 2008a), a more complex menu of assets (including land) could be introduced, but this would only complicate matters for the purpose at hand.
} 
Real consumption expenditure by households, $C$, depends positively on labor income, $W N$, and the real value of wealth (which captures a real balance effect), as well as negatively on the real deposit rate (which captures intertemporal effects). ${ }^{10}$ Thus, consumption spending can be written as:

$$
C=\alpha_{1} \frac{\bar{W} N}{P}-\alpha_{2}\left(i_{D}-\pi^{a}\right)+\alpha_{3}\left(\frac{A_{0}^{H}}{P}\right),
$$

where $\pi^{a}$ is the exogenous expected inflation rate, $\alpha_{1} \in(0,1)$ the marginal propensity to consume out of disposable income, $A_{0}^{H}$ the beginning-of-period value of financial wealth, and $\alpha_{2}, \alpha_{3}>0$. The positive effect of current income on consumption is consistent with the evidence regarding the pervasiveness of liquidity constraints in low- and middle-income countries (as documented by Agénor and Montiel (2008b)) and the implicit assumption that households cannot borrow directly from banks to smooth consumption. By implication, the value of $\alpha_{2}$ should be relatively small, a fact also corroborated by the available evidence.

\subsection{Commercial Bank}

Assets of the commercial bank consist of credit extended to firms, $L^{F}$, mandatory reserves held at the central bank, $R R$, excess reserves held as cash in vault, $V$, and government bonds, $B^{B}$. The bank's liabilities consist of household deposits, $D$, and borrowing from the central bank, $L^{B}$. The balance sheet of the representative commercial bank can therefore be written as:

$$
L^{F}+R R+V+B^{B}=D+L^{B},
$$

\footnotetext{
${ }^{10}$ Recall that profits are distributed only at the end of each period. For simplicity, we also assume that interest on bonds and deposits are paid at the end of the period; current income consists therefore only of wages.
} 
where all variables are measured in nominal terms. Reserves held at the central bank pay no interest and are set in proportion to deposits:

$$
R R=\mu D
$$

where $\mu \in(0,1)$.

For simplicity of exposition, the bank's behavior is characterized in two stages: we first examine the determination of interest rates, and then derive the desired level of excess reserves.

\subsubsection{Interest Rate Pricing Rules}

The bank sets both deposit and lending interest rates, taking the level of excess reserves as given. It views household deposits and loans from the central bank as perfect substitutes at the margin, and is indifferent as to the composition of its liabilities. Accordingly, the (gross) interest rate on deposits must be equal to the (gross) cost of funds provided by the central bank, corrected for the cost of holding reserve requirements on deposits: ${ }^{11}$

$$
1+i_{D}=\left(1+i_{R}\right)(1-\mu)
$$

Other than the central bank, the bank is the only holder of government debt. The interest rate that it demands on government bonds, $i_{B}$, is set as a premium over the marginal cost of funds. Given that central bank liquidity is perfectly elastic at the prevailing refinance rate, this cost is simply $i_{R}$ :

$$
1+i_{B}=\left(1+\theta_{B}\right)\left(1+i_{R}\right)
$$

where $\theta_{B}$ is the risk premium on government bonds. We assume that this premium is increasing in the debt-to-output ratio, which is a measures of the

\footnotetext{
${ }^{11}$ See Freixas and Rochet (1997, pp. 55-56) and Agénor and Montiel (2008) for a formal derivation of pricing rules similar to (14) and (17). Here we abstract from intermediation costs.
} 
sustainability of public debt: ${ }^{12}$

$$
\theta_{B}=\theta_{B}\left(B^{B} / Y\right)
$$

where $\theta_{B}^{\prime}>0$.

The contractual lending rate, $i_{L}$, is set as a premium over the prevailing interest rate on government bonds, which represents the rate of return on alternative assets:

$$
1+i_{L}=\left(1+\theta_{L}\right)\left(1+i_{B}\right)
$$

where the risk premium, $\theta_{L}$, is taken to be inversely related to the ratio of firms' assets (the value of their beginning-of-period physical capital stock, $K_{0}$, times $P$, the price of the good) over their liabilities, that is, beginningof-period borrowing, $L_{0}^{F}$ :

$$
\theta_{L}=\theta_{L}\left(\frac{P \cdot K_{0}}{L_{0}^{F}}\right)
$$

where $\theta_{L}^{\prime}<0$. Thus, an increase in prices, by improving firms' net worth, tends to reduce the risk premium demanded by the bank. ${ }^{13}$ To the extent that $P K_{0}$ is interpreted as a measure of assets that lenders can seize in case of default, this specification is also consistent with more elaborate models emphasizing the role of collateral in reducing moral hazard - that is, incentives to take on excessive risk - as developed for instance by Boot, Thakor, and Udell (1991) and Bester (1994).

\footnotetext{
${ }^{12}$ Alternatively, with $\tau \in(0,1)$ denoting a constant tax rate, the premium could be specified as $B^{B} / \tau W N$, with the numerator measuring the government's capacity to tax. The specification in (16) is more tractable.

${ }^{13}$ If the risk premium jumps at particular levels of net worth, then $\theta_{L}(\cdot)$ would not be continuously differentiable. In such conditions, one can only focus on each segment of the loan schedule. To avoid such complications, we assume that $\theta_{L}$ is everywhere continuously differentiable. We make the same assumptions for $\theta_{B}$ as well.
} 


\subsubsection{Demand for Excess Reserves}

We now derive the demand for excess reserves, taking interest rates as given, using a simple framework. ${ }^{14}$ Suppose that with probability $q$ households face a liquidity shock, due for instance to an unexpected withdrawal need. This liquidity need is proportional to the level of deposits at the beginning of period, $D_{0}$. Thus, the bank needs to provide liquidity $\gamma D_{0}$, where $\gamma \in(0,1)$, with probability $q$.

The bank can access liquidity either by holding unremunerated excess reserves, $V$, as cash in vault, or by borrowing from the central bank, at the constant (marginal) rate $i_{R}$, because the central bank's supply of liquidity is perfectly elastic at that rate. However, these two sources of liquidity are not identical because direct and indirect costs are not the same. In particular, given the structure of the bank's assets, and the fact that the quantity of bank loans is demand determined, the opportunity cost of holding reserves is thus $i_{B}{ }^{15}$

Optimal holdings of reserves are thus determined by the following cost minimization problem, in which the bank weighs the opportunity cost of holding reserves, $i_{B} V$, against that of borrowing from the central bank:

$$
\min _{V} U\left[i_{B} V, q\left(\gamma D_{0}-V\right) i_{R}\right]
$$

where $\gamma D_{0}-V$ denotes the net amount of liquidity provided by the central bank in case of a reserve shortfall. ${ }^{16}$ For tractability, suppose that both terms

\footnotetext{
${ }^{14}$ For an explicit derivation of a demand function for excess reserves in a stochasic setting, see Agénor, Aizenman, and Hoffmaister (2004).

${ }^{15}$ Put differently, given that the supply of loans is perfectly elastic at the prevailing lending rate, the actual amount of credit is determined by firms, given their borrowing needs defined in (7); the opportunity cost of holding excess reserves is thus the bond rate.

${ }^{16}$ Although the bank faces a perfectly elastic supply of liquidity at the rate $i_{R}$, we could assume that holding some excess cash in its vaults (say, $V_{m}>0$ ) is always desirable to
} 
in the objective function $U$ enter quadratically, so that the minimization problem becomes

$$
\min _{V}\left\{\frac{1}{2}\left(i_{B} V\right)^{2}+\frac{\chi}{2}\left[q\left(\gamma D_{0}-V\right) i_{R}\right]^{2}\right\},
$$

where $\chi>0$ measures relative preferences.

Solving (20) yields the first-order condition

$$
i_{B}^{2} V-\chi\left(q i_{R}\right)^{2}\left(\gamma D_{0}-V\right)=0
$$

which implies

$$
\frac{V^{d}}{\gamma D_{0}}=\frac{\chi\left(q i_{R}\right)^{2}}{i_{B}^{2}+\chi\left(q i_{R}\right)^{2}}=v\left(i_{B} ; i_{R}, q\right),
$$

with $v_{1}<0$, and $v_{2}, v_{3}>0$. A higher cost of borrowing from the central bank, or an increase in the probability of unexpected withdrawal, raise excess reserves, whereas an increase in the bond rate tends to reduce them.

\subsubsection{Borrowing from Central Bank}

Given that firms' demand for credit determines the actual supply of loans, that the bank absorbs all bonds that are not held by the central bank, and that required reserves are fixed by government fiat, the balance sheet condition (12) can be solved residually for borrowing from the central bank: ${ }^{17}$

$$
L^{B}=L^{F}+R R+V+B^{B}-D .
$$

avoid any inconvenience to depositors - in terms of the time spent waiting for tellers to physically go to the central bank and withdraw cash-who show up unexpectedly. This could be easily handled by defining the opportunity cost in $(20)$ as $i_{B}\left(V-V_{m}\right)$ only.

${ }^{17}$ With $L^{B}$ exogenous instead, it could also be assumed that excess reserves (if they are sufficiently large to begin with) are a "shock absorber", determined residually from (22), instead of (21). In that case, monetary policy changes that take the form of changes in $L^{B}$ would have no effect on the economy. 
Using (7), (10), and (38), this equation becomes: ${ }^{18}$

$$
L^{B}=\bar{W} N^{d}\left(P ; i_{R}\right)+P I+\gamma D_{0} v\left(i_{B} ; i_{R}\right)+B^{B}-(1-\mu) \kappa\left(i_{D}\right) A^{H} .
$$

\subsection{Central Bank and Government}

The balance sheet of the central bank consists, on the asset side, of loans to the commercial bank, $L^{B}$, and government bonds, $B^{C}$. On the liability side, it consists only of the monetary base, $M B$ :

$$
B^{C}+L^{B}=M B
$$

with the monetary base given also by the sum of currency in circulation and reserves:

$$
M B=B I L L+R R+V
$$

Because the supply of liquidity by the central bank is perfectly elastic at the rate $i_{R}$, the monetary base is endogenous; this implies, using (13), that the supply of currency is

$$
B I L L=M B-\mu D-V .
$$

The government spends on goods, in quantity $G$. The outstanding stock of bonds, $B=B^{C}+B^{B}$, is taken as given.

\subsection{Investment and Goods Market}

In standard fashion, real investment is taken to be negatively related to the real lending rate, $i_{L}-\pi^{a}$ :

$$
I=I\left(i_{L}-\pi^{a}\right)
$$

\footnotetext{
${ }^{18}$ Note that in the present setting the bank's profits are not necessarily zero, but are given instead by $i_{L} L^{F}+i_{B} B^{B}-i_{D} D-i_{R} L^{B}$. Just like firms' profits, we assume that this income is distributed to households only at the end of the period.
} 
where $I^{\prime}<0$. As already acknowledged in (7), all investment is financed by bank loans.

Finally, the equilibrium condition of the goods market is given by:

$$
Y^{s}\left(P ; i_{R}\right)=C+I+G .
$$

\section{Model Solution}

The solution of the model above follows a similar logic as in Agénor and Montiel (2006, 2008a). Essentially, macroeconomic equilibrium requires simultaneous equality between supply and demand in the markets for five financial assets (currency, bank deposits, government bonds, bank loans, and central bank credit), as well as the goods market. By Walras' Law, the asset market equilibrium conditions are not independent of each other; one of them can be derived residually from the other equations, and can therefore be eliminated.

The market for bank deposits is always in equilibrium, because the bank accepts all deposits that household wish to make at the rate $i_{D}$. The market for bank loans is also always in equilibrium, because the bank provides all the credit demanded by firms at the rate $i_{L}$. Similarly, the market for public bonds is always in equilibrium given that the bank is willing to hold all the government debt that the central bank is not holding, at the (premiuminclusive) rate $i_{B}$. And the market for central bank credit is always in equilibrium, given that the assumption that the central bank fixes the policy interest rate $i_{R}$ and supplies all the liquidity demanded by the bank at that rate. Somewhat naturally in the present setting, we can therefore eliminate the market for currency.

The next step is to solve for the loan interest rate. Equations (6) and 
(15) to (18) yield

$$
i_{L}=\left[1+\theta_{L}\left(\frac{P K_{0}}{L_{0}^{F}}\right)\right]\left[1+\theta_{B}\left\{\frac{B^{B}}{Y^{s}\left(P ; i_{R}\right)}\right\}\right]\left(1+i_{R}\right)-1,
$$

which can be written as

$$
i_{L}=\mathbf{F F}\left(P ; i_{R}, \mu\right)
$$

where

$$
\begin{gathered}
\frac{\partial i_{L}}{\partial P}=\mathbf{F F}_{1}=\left\{\left(\frac{K_{0}}{L_{0}^{F}}\right) \theta_{L}^{\prime}\left(1+\theta_{B}\right)-\left(1+\theta_{L}\right) \theta_{B}^{\prime} \frac{B^{B}}{Y^{s 2}} Y_{1}^{s}\right\}\left(1+i_{R}\right)<0, \\
\frac{\partial i_{L}}{\partial i_{R}}=\mathbf{F F}_{2}=\left(1+\theta_{L}\right)\left\{\left(1+\theta_{B}\right)-\theta_{B}^{\prime} \frac{B^{B}}{Y^{s 2}} Y_{2}^{s}\right\}>0 \\
\frac{\partial i_{L}}{\partial \mu}=0 .
\end{gathered}
$$

A rise in prices lowers the equilibrium loan rate, whereas an increase in the refinance rate raises the lending rate, both directly and indirectly. Note also that a change in the required reserve ratio, $\mu$, has no direct effect on the lending rate; with the marginal cost of funds set by the refinance rate, this variable affects directly only the deposit rate.

Turning to the real sector, using equations (6), (11), and (27), and setting $\pi^{a}=0$, we can write the goods market equilibrium condition, equation (28), as:

$$
Y^{s}\left(P ; i_{R}\right)=\left\{\alpha_{1}\left(\frac{\bar{W}}{P}\right) N^{d}\left(P ; i_{R}\right)-\alpha_{2} i_{D}+\alpha_{3}\left(\frac{A_{0}^{H}}{P}\right)\right\}+I\left(i_{L}\right)+G
$$

Using (14) to eliminate $i_{D}$, this equation implicitly defines a set of combinations of the loan interest rate and the price level that are consistent with equilibrium in the goods market. This set is given by:

$$
i_{L}=\mathbf{G G}\left(P ; i_{R}, \mu\right),
$$


where

$$
\begin{gathered}
\frac{\partial i_{L}}{\partial P}=\mathbf{G G}_{1}=\frac{1}{I^{\prime}}\left\{Y_{1}^{s}-\alpha_{1}\left(\frac{\bar{W}}{P^{2}}\right)\left(P N_{1}^{d}-N^{d}\right)+\alpha_{3}\left(\frac{A_{0}^{H}}{P^{2}}\right)\right\} \lessgtr 0, \\
\frac{\partial i_{L}}{\partial i_{R}}=\mathbf{G G}_{2}=\frac{1}{I^{\prime}}\left\{Y_{2}^{s}-\alpha_{1}\left(\frac{\bar{W}}{P}\right) N_{2}^{d}+\alpha_{2}(1-\mu)\right\} \lessgtr 0, \\
\frac{\partial i_{L}}{\partial \mu}=\mathbf{G G}_{3}=-\frac{\alpha_{2}\left(1+i_{D}\right)}{I^{\prime}}>0,
\end{gathered}
$$

A rise in prices affects equilibrium in the goods market (and thus the lending rate) in three different ways. First, it tends to reduce consumption, through a negative real balance effect. Second, it tends to reduce the real wage and to boost aggregate supply. Third, the increase in labor demand tends to increase wage income, whereas the increase in prices tends to lower it; the net effect on distributed wage income is in general ambiguous and depends on the sign of $P N_{1}^{d}-N^{d}$, or equivalently on the price elasticity of labor demand, $P N_{1}^{d} / N^{d}$. If that elasticity is lower than unity in absolute value, distributed income will increase, thereby stimulating consumption. The net effect on the lending rate is in general ambiguous, and depends on the relative shifts in supply (which increases unambiguously) and aggregate demand (which may or may not increase, depending on the behavior of private spending).

An increase in the refinance rate lowers aggregate demand through the negative intertemporal effect of the deposit rate on consumption. At the same time, it also reduces goods supply (through its effect on the effective cost of labor, captured through $Y_{2}^{s}$ ) and therefore factor income. The second effect (captured by the term $\alpha_{1} \bar{W} N_{2}^{d}$ ) compounds the direct negative effect on demand. Because aggregate supply and aggregate demand both fall, the lending rate may either increase or fall to maintain equilibrium in the goods 
market. By contrast, an increase in the required reserve ratio lowers the deposit rate, which tends to raise present consumption; to maintain equilibrium in the goods market, at the initial level of prices, investment must fall and this requires a rise in the lending rate.

Equations (29) and (30) can be solved together for the equilibrium values of the loan interest rate $i_{L}$ and the goods price $P$. The solution is depicted graphically in Figure 1. In the northeast quadrant, curve $F F$ represents the financial-market equilibrium curve (29), whereas curve $G G$ represents the goods-market equilibrium curve (30). As shown earlier, $F F$ has a negative slope, whereas $G G$ may have a positive or a negative slope. ${ }^{19}$ In the case shown in the figure a negative slope is assumed. Under standard dynamic assumptions, local stability requires $G G$ to be steeper than $F F$. The southeast quadrant displays a concave curve representing goods supply, $Y^{s}$, as an increasing function of prices. In the northwest quadrant, the negative relationship (27) between investment and the (real) lending rate is shown. Using the 45-degree line to report $Y^{s}$ and $I$ in the southwest quadrant gives the sum of private and public spending, $C+G$. The economy's equilibrium is determined at points $E, D, H$, and $J$.

It is worth noting that, in this basic framework, excess liquid reserves play no direct role in the determination of macroeconomic equilibrium. As shown by equation (23), they affect only borrowing by the bank from the central bank, which is determined residually. By implication, given that the supply of liquidity is perfectly elastic at the prevailing refinance rate, there is no "excess reserve" channel for monetary policy in this setting.

\footnotetext{
${ }^{19}$ Using the normalization $\bar{W}=P=1$, and the linear approximation $Y_{1} \simeq \alpha N_{1}^{d}$, we must have, for $\partial i_{L} /\left.\partial P\right|_{G G}<0$, and given that $I^{\prime}<0,\left(\alpha-\alpha_{1}\right) N_{1}^{d}+\alpha_{1} N^{d}+\alpha_{3} A_{0}^{H}>0$. In turn, given that $N_{1}>0$, a sufficient (although not necessary) condition for this condition to hold is $\alpha>\alpha_{1}$. See Agénor and Montiel (2008a) for a further discussion of this condition.
} 


\section{Impact of Monetary Policy}

To illustrate the functioning of the basic framework, we consider an increase in the reserve requirement rate, $\mu$, and a rise in the refinance rate, $i_{R}$.

An increase in $\mu$ induces the bank to reduce the deposit interest rate, which in turn discourages saving and stimulates current consumption. The excess demand for goods leads to an increase in prices (and thus a higher value of collateral), which induces the bank to charge a lower premium. The lower lending rate stimulates investment. At the same time, by lowering the cost of labor, the increase in prices raises output. The adjustment process is summarized in Figure 2; $G G$ shifts upward in the northeast quadrant, but because the increase in $\mu$ has no effect on the bank's marginal cost of funds, $F F$ does not change. The new equilibrium (point $E^{\prime}$ ) is therefore characterized by a lower lending rate and higher prices.

An increase in the refinance rate raises the bank's borrowing costs, which induces them to raise the lending rate. Graphically, as illustrated in Figure 3 , this leads to an upward shift in $F F$. At the same time, the increase in $i_{R}$ raises the deposit rate directly, which induces households to save more and spend less now. In addition, however, the increase in the effective cost of labor reduces aggregate supply and factor income. As noted earlier, the negative income effect compounds the adverse intertemporal substitution effect on private expenditure. But because aggregate supply and aggregate demand both fall, the lending rate may either increase or fall (at the initial level of prices) to maintain equilibrium in the goods market. In the northeast quadrant of Figure 3, GG may either shift to the left, leading to a new equilibrium point $E^{\prime}$, or to the right, leading to a new equilibrium at $E^{\prime \prime}$. In both cases, the net effect is an increase in the equilibrium lending rate, but 
in the former prices fall, whereas in the second they increase.

As shown in the southeast quadrant, the increase in $i_{R}$ shifts the supply curve inward. Regardless of whether $P$ rises or falls, in the case shown there is a contraction in goods supply (from $H$ to $H^{\prime}$, or from $H$ to $H^{\prime \prime}$ ), due not only to the direct increase in the cost of working capital, but possibly also because of an increase in real wages. ${ }^{20}$ Investment falls from $D$ to either $D^{\prime}$ or $D^{\prime \prime}$, whereas the net effect on consumption is ambiguous - the direct effect of the higher deposit rate is to lower private spending, but the drop in prices leads to a positive real balance effect. Thus, a key feature of the model is that a contractionary monetary policy is capable of generating a "stagflationary" effect.

It is worth noting that the equilibrium increase in the lending rate can be decomposed into two effects. The first is a direct "pass-through" effect, represented by the movement from $E$ to $B$ in the northeast quadrant. The second is either a financial "accelerator" effect (movement from $B$ to $E^{\prime}$ ), if prices fall in equilibrium, or a financial "decelerator" effect (movement from $B^{\prime}$ to $\left.E^{\prime \prime}\right)$, if prices rise in equilibrium. In both cases, the second effect) results from a gradual change in the risk premium, in response to changes in the value of collateral pledged by firms. It is consistent with the BernankeGertler effect, emphasized in much of the recent literature, on monetary policy (see, for instance, Gertler, Gilchrist, and Natalucci (2007)).

\footnotetext{
${ }^{20} \mathrm{In}$ principle, it is possible for $G G$ to shift so much to the right that the end result is a lower lending rate (as a result of strong collateral effects) and a large increase in prices - both of which could combine to lead to an increase in supply. However, this is an implausible case.
} 


\section{Excess Liquidity and Pricing Behavior}

In the foregoing discussion, excess reserves play no role in the determination of macroeconomic equilibrium and the transmission process of monetary policy; the bank holds the desired level of reserves (above and beyond those required by law) to protect itself from unexpected withdrawals, taking into account the opportunity cost of holding cash. Thus, desired reserves represent voluntary holdings of liquidity.

However, as noted in the introduction, banks may find themselves with more liquidity than they desire. We define excess liquidity as a situation where the actual (beginning-of-period) stock of excess reserves exceeds the desired level, that is, $V_{0}>V^{d}$. Thus, in a sense, $V_{0}-V^{d}$ measures the involuntary accumulation of liquidity. ${ }^{21}$ We examine next how excess liquidity affect bank pricing behavior, by considering in turn deposit and lending rates.

Before we do so, however, we need to clarify a technical issue. In principle, in the model, stocks are adjusted at the end of each period. However, in order to assess the implications of excess liquidity for the within-period (flow) equilibrium, we need to change this timing assumption for the bank's demand for reserves. Specifically, in a manner similar to Agénor and Montiel (2007) in their discussion of the behavior of foreign-currency deposits held abroad, we can assume that banks adjust their actual excess reserves continuously (rather than at the end of each period) toward their desired value, following a partial adjustment process of the form

$$
V-V_{0}=\lambda\left(V^{d}-V_{0}\right)
$$

\footnotetext{
${ }^{21}$ As noted in the introduction, there are a number of reasons why actual excess reserves may exceed the desired level. For our purpose here, however, identifying a precise motive is not necessary.
} 
where $\lambda \in(0,1)$ is the speed of adjustment. Thus the correct measure of excess liquidity should be, instead of $V_{0} / V^{d}$,

$$
\frac{V}{V^{d}}=\frac{\lambda V^{d}+(1-\lambda) V_{0}}{V^{d}}=\lambda+(1-\lambda)\left(\frac{V_{0}}{V^{d}}\right) .
$$

However, as long as $\lambda$ is constant, this does not affect qualitatively our subsequent results because we only use general functional forms. ${ }^{22}$ Thus, for simplicity, we will continue cast our discussion in terms of $V_{0} / V^{d}$.

\subsection{Deposit Rates}

In the present setting, there are two implications of excess liquidity on deposit rate setting. The first is that the deposit rate may become less sensitive to changes in policy rates. This can be captured by replacing equation (14) by

$$
1+i_{D}=\left(1+i_{R}\right)(1-\mu) f\left(\frac{V_{0}}{V^{d}}\right)
$$

where $f$ is a piecewise function satisfying

$$
f(x)=\left\{\begin{array}{l}
1 \text { for } 0<x \leq 1 \\
0<f(x)<1 \text { for } x>1
\end{array}\right.
$$

and $f^{\prime}(x)<0$ for $x>1$, and $\lim _{x \rightarrow \infty} f(x) \rightarrow 0$. These restrictions on $f$ imply that an increase in excess liquidity imparts greater stickiness to the deposit rate. In the limit, if the degree of excess liquidity is very high, the deposit rate tends to zero. In a sense, excess liquidity induces banks to discourage deposits by offering no return on them. ${ }^{23}$ Thus, in this formulation, the impact of a change in monetary policy instruments $\left(i_{R}\right.$ or $\left.\mu\right)$ is symmetric; essentially, excess liquidity is accompanied with less efficient pricing. One reason for that is that excess liquidity is accompanied by (or results from)

\footnotetext{
${ }^{22}$ In a dynamic framework, however, the implications would be quite different.

${ }^{23}$ This behavior has been observed in various countries in recent years; see Agénor and El Aynaoui (2007) for the case of Morocco.
} 
an increase in volatility; banks may therefore be more cautious in changing deposit rates, in order to avoid exacerbating underlying volatility factors by inducing portfolio shifts.

An alternative and perhaps more plausible implication of excess liquidity is that the bank may respond asymmetrically when adjusting deposit rates. Specifically, it may be less responsive to increases in the refinance rate, or to reductions in the required reserve ratio, because it internalizes the fact that raising the deposit rate may induce households to shift more of their assets into bank deposits - thereby increasing the actual stock of reserves at the beginning of the next period and therefore compounding (all else equal) the initial problem of excess liquidity. For the opposite reason, the bank would tend to be fully responsive to reductions in the refinance rate, or increases in the required reserve ratio, as predicted by the arbitrage equation (14).

These asymmetric effects can be captured by specifying the response of the deposit rate to a change in the official rate as

$$
\frac{d i_{D}}{d i_{R}}=\left\{\begin{array}{ll}
1-\mu & \text { if } d i_{R}<0 \\
(1-\mu) f\left(V_{0} / V^{d}\right) & \text { if } d i_{R}>0
\end{array},\right.
$$

whereas the response to a change in the required reserve ratio can be specified as

$$
d i_{D} / d \mu=\left\{\begin{array}{ll}
-\left(1+i_{R}\right) & \text { if } d \mu>0 \\
-\left(1+i_{R}\right) f\left(V_{0} / V^{d}\right) & \text { if } d \mu<0
\end{array} .\right.
$$

Thus, excess liquidity imparts only upward stickiness in the response of the deposit rate to changes in monetary policy instruments. Equation (33) is consistent with the econometric evidence provided by Gropp, Sorensen, and Lichtenberg (2007) for Euro area countries. Although they do not identify explicitly excess liquidity as a potential culprit, they found that an increase in policy rates has a slower pass-through effect on bank deposit rates. It is also consistent with the upward rigidity in deposit rates found by Chong, Liu, and 
Shrestha (2006) for Singapore. More importantly for our purpose, Lebedenski (2007) provides explicit evidence for Morocco showing that deposit interest rates are more sticky upward in the presence of excess liquidity.

To examine the implications of these pricing rules for monetary policy, note first that using (6), (15) and (16) yields

$$
i_{B}=\left\{1+\theta_{B}\left[\frac{B^{B}}{Y^{s}\left(P ; i_{R}\right)}\right]\right\}\left(1+i_{R}\right)-1
$$

where, as noted earlier, $\theta_{B}^{\prime}>0$. This equation can be rewritten as

$$
i_{B}=J^{B}\left(P ; i_{R}\right)
$$

with

$$
\begin{gathered}
\frac{\partial i_{B}}{\partial P}=J_{1}^{B}=\left(1+i_{R}\right) \theta_{B}^{\prime} B^{B} \frac{Y_{1}^{s}}{Y^{s 2}}<0 \\
\frac{\partial i_{B}}{\partial i_{R}}=J_{2}^{B}=\left(1+\theta_{B}\right)-\left(1+i_{R}\right) \theta_{B}^{\prime} B^{B} \frac{Y_{2}^{s}}{Y^{s 2}}>0 .
\end{gathered}
$$

An increase in prices lowers the bond rate, because it leads to lower real wages and higher activity - thereby reducing the debt-to-output ratio and the risk premium. By contrast, an increase in the refinance rate raises the bond rate, both through a direct arbitrage effect and a higher risk premium resulting from a reduction in output.

Combining (21) with (31) and (35) yields

$$
i_{D}=J^{D}\left(P ; i_{R}, \mu\right)
$$

where

$$
\begin{gathered}
\frac{\partial i_{D}}{\partial P}=-\left(1+i_{R}\right)(1-\mu) f^{\prime}\left(\frac{v_{1} J_{1}^{B}}{v^{2}}\right)>0, \\
\frac{\partial i_{D}}{\partial i_{R}}=(1-\mu)\left\{f(\cdot)-\left(1+i_{R}\right)\left(\frac{f^{\prime}}{V^{d}}\right)\left(\frac{V_{0}}{V^{d}}\right)\left(v_{1} J_{2}^{B}+v_{2}\right)\right\} \lessgtr 0, \\
\frac{\partial i_{D}}{\partial \mu}=-\left(1+i_{R}\right) f(\cdot)<0 .
\end{gathered}
$$


An increase in prices, by lowering the bond rate (the opportunity cost of holding cash), reduces excess liquidity and raises the deposit rate. A higher required reserve ratio lowers the deposit rate, to an extent that depends on the initial level of excess reserves. An increase in the refinance rate, however, has now an ambiguous effect; the direct effect is positive, but the indirect, "excess liquidity" effect, is ambiguous. Given that $f^{\prime}<0$, the sign of this effect depends on $v_{1} J_{2}^{B}+v_{2}$, where $v_{1}<0$ and $J_{2}^{B}, v_{2}>0$. In addition, however, if the initial degree of excess liquidity is relatively small, in the sense that $V_{0} / V^{d}$ is close to unity, this term has a limited impact on $\partial i_{D} / \partial i_{R}$, which therefore may well remain positive.

We will therefore consider separately the two cases, $\partial i_{D} / \partial i_{R}>0$ (low excess liquidity) and $\partial i_{D} / \partial i_{R}<0$ (high excess liquidity). The first case corresponds essentially to the scenario analyzed earlier. The difference now is that the downward pressure on prices created by the initial excess supply of goods leads to a further reduction in $i_{D}$, as implied by (36); this exacerbates the contraction in aggregate demand. Qualitatively, however, the results are similar to those illustrated in Figure 3, with a shift in equilibrium from $E$ to $E^{\prime}$ if supply is not overly responsive.

Consider now the case where $\partial i_{D} / \partial i_{R}<0$. The intertemporal effect leads now to an increase in consumption and aggregate demand. Thus, even if the increase in the refinance rate exerts no direct contractionary effect on output (that is, even in the absence of a cost channel), a restrictive monetary policy may lead to an increase in prices. Graphically, therefore curve $G G$ may shift to the right, as shown in Figure 3, with the new equilibrium being at $E^{\prime \prime}$. Even in the absence of a cost channel, with output totally unresponsive to changes in the refinance rate - that is, $Y_{2}^{s}=0$, which implies that the upward-sloping curve in the southeast quadrant of the figure does not shift in response to 
an increase in $i_{R}$ - supply would still increase, due to the reduction in real wages induced by higher prices. Bank behavior under excess liquidity may therefore lead to a "price puzzle" associated with a tightening of monetary policy (see Castelnuovo and Surico (2006)).

Consider now the case of asymmetric response, as captured by equations (33) and (34). The key difference now is that it is possible that the bank may choose not to change at all its deposit rate in response to an increase in the refinance rate; in this case, $d i_{D} / d i_{R}=0$ and monetary policy based on adjustments in the cost of borrowing becomes totally ineffective. ${ }^{24}$ The same result may hold with respect to a reduction in the required reserve ratio. By contrast, with excess liquidity, the bank may be more willing to cut deposit rates following either a reduction in the refinance rate or an increase in the required reserve ratio, given that both policies (as indicated earlier) would lead to a reduction in the supply of deposits by households. In a sense, the model provides a microeconomic rationale for the decision, often observed in practice, to raise required reserve ratios to "sterilize" excess liquidity.

Of course, if banks choose not to adjust deposit rates at all following an increase in the refinance rate, private consumption would not change initially (because there are no incentives to shift spending across periods), and aggregate demand would drop only to the extent that investment falls (because of the direct pass-through effect on the lending rate). To the extent that the adverse supply-side effect dominates the contraction in investment, the net effect would be higher prices than otherwise - thereby mitigating, in turn, the initial drop in output through a cut in the real wage. Thus, as illustrated in Figure 3, the "stagflationary" effect associated with a tight

\footnotetext{
${ }^{24}$ This occurs because, in (33), with $f$ being monotonic for $x>1$ and with $f^{\prime}<0$, it is possible for $f(x) \rightarrow 0$ for $x \rightarrow \infty$.
} 
monetary policy in the presence of a cost channel is characterized by a higher price effect, and a smaller output effect, in the presence of excess liquidity.

\subsection{Risk Premium and Lending Rates}

Regarding the impact of excess liquidity on the formation of lending rates, there are also symmetric and asymmetric effects. In the first case, excess liquidity may induce the bank to soften collateral requirements or more generally ease credit standards (that is, the criteria applied when evaluating borrowers' creditworthiness), in order to stimulate the demand for loans and attract customers. Put differently, the greater the degree of excess liquidity, the more banks may be willing to weaken the procedures that they normally use for checking the creditworthiness of potential borrowers, such as performance indicators (profits and sales data, financial viability ratios, etc.), credit exposure limits, and other standard contract terms or loan covenants (related, for instance, to hazard insurance and guarantee requirements) because loans bear interest whereas excess reserves do not. ${ }^{25}$

Formally, this effect can be captured by assuming that the risk premium is now determined by, instead of (18),

$$
\theta_{L}=\theta_{L}\left(\frac{P K_{0}}{L_{0}^{F}}, \frac{V_{0}}{V^{d}}\right)
$$

where, as before, $\theta_{L 1}<0$, and $\theta_{L 2}<0$. Note that another way to capture the possibility that the bank respond to excess liquidity by easing collateral requirements and credit standards would be to let also (the absolute value of) the partial derivative $\theta_{L 1}$ depend positively on $V_{0} / V^{d}$, for $V_{0} / V^{d}>1$.

\footnotetext{
${ }^{25}$ Another possibility is that the supply of loans is no longer perfectly elastic at the prevailing lending rate in situations of excess liquidity. For instance, if banks perceive the environment to be more risky they may not willingly make many loans and would instead find themselves holding large stocks of liquid assets. However, they would also reduce deposit rates (as shown in (31)) and this would tend to reduce excess liquidity.
} 
In such conditions, the bank would be enclined to lower the premium more significantly in response to an improvement in borrowers' net worth. For expositional simplicity, however, we will focus on the case where $\theta_{L 1}$ is constant.

The implications of this change in bank behavior are twofold. First, it mitigates the role of net worth considerations. All else equal, the premium (and thus the lending rate) would tend therefore to be lower in the presence of excess liquidity. Second, an increase in the refinance rate now has in general an ambiguous effect on the lending rate. ${ }^{26}$ To establish this result, note first that from (21),

$$
\frac{\partial V^{d}}{\partial i_{R}}=v_{1}\left(\frac{\partial i_{B}}{\partial i_{R}}\right)+v_{2},
$$

with $v_{1}<0$ and $v_{2}>0$. From (35), we have $\partial i_{B} / \partial i_{R}>0$. Thus while an increase in the refinance rate tends to increase the demand for reserves through its direct cost effect, it also tends to reduce it, through its positive effect on the opportunity cost of reserves (that is, the bond rate). If the second effect dominates, so that voluntary cash holdings fall and excess liquidity $V_{0} / V^{d}$ increases, there will be a reduction in the risk premium, at the initial level of prices.

From (17) and (37), if the reduction in the premium outweighs the direct effect of the marginal cost of borrowing from the central bank, the net effect of an increase in the refinance rate may well be a fall in the lending rate. If so, the impact of the policy shock may well turn out to be stagflationary: because there is a contraction in supply (at the initial real wage) while investment rises, consumption must fall. For this to happen, prices must increase, so that the intertemporal substitution effect is complemented with a negative

\footnotetext{
${ }^{26} \mathrm{~A}$ change in reserve requirement rates has no direct effect on lending rates, regardless of whether the economy is or isn't in a state of excess liquidity.
} 
wealth effect. Although the increase in prices stimulates output by reducing the "gross" real wage, the net effect on the effective cost of labor may still be positive -implying that the presence of the cost channel makes the overall effect on output contractionary.

\section{Concluding Remarks}

It has often been observed that when banks hold liquid funds in excess of their desired level, the transmission mechanism of monetary policy may be considerably altered. The purpose of this paper has been to propose a simple macroeconomic model that allows a formal analytical exploration of the implications of excess bank liquidity for the effectiveness of monetary policy. In the model, a cost channel is introduced by assuming that firms must borrow to pay wages prior to the sale of output. Banks set both deposit and lending rates, in the latter case as a premium over the cost of borrowing from the central bank. The premium itself depends on firms' net worth, in the Bernanke-Gertler tradition. Firms do not face binding credit constraints but are able to borrow funds only at ever higher interest rates. A demand function for excess reserves is also derived explicitly, under the assumption that banks face uncertainty about cash withdrawals by the public.

The basic model was used to examine the financial and real effects of a change in the cost of borrowing from the central bank and the required reserve ratio, in a "standard" case where excess liquidity (defined as a situation where actual excess reserves exceed the desired value) exerts no direct effect on bank pricing behavior. It was shown, in particular, that because aggregate supply and aggregate demand both fall, prices may either increase or fall. In the former case, a familiar Bernanke-Gertler financial accelerator effect 
was identified, as a result of endogenous changes in net worth in the risk premium. In the latter, however, a financial "decelerator" may be at play, for similar reasons.

The analysis was then extended to consider the case of excess liquidity and account for symmetric and asymmetric effects that it may exert on bank pricing rules. In the first case, deposit rates are assumed to respond symmetrically to changes in monetary policy instruments, whereas in the second they are assumed to exhibit upward rigidity only in response to these changes. Under symmetric effects, we found that excess liquidity may lead to a "price puzzle," that is, an inflationary effect of contractionary monetary policy. With asymmetric effects, banks may be more willing to cut deposit rates following either a reduction in the refinance rate or an increase in the required reserve ratio, given that both policies lead to a reduction in the supply of deposits by households. The model therefore provides a rationale for the decision (common in practice) to raise required reserve ratios to "sterilize" excess liquidity. In addition, we found that even if banks choose not to adjust deposit rates at all following an increase in the refinance rate, under excess liquidity the stagflationary effect associated with a tight monetary policy in the presence of a cost channel may be exacerbated.

We also considered the case where excess liquidity leads to asymmetric behavior in setting lending rates, by inducing banks (in an attempt to stimulate the demand for credit) to relax credit standards. We argued that such behavior may well bring about a reduction in the risk premium charged by banks, which may be large enough to offset the direct (positive) effect of an increase in the refinance rate on the lending rate. In such conditions, and as long as the effective real wage (inclusive of interest costs) increases, a contractionary monetary policy is again likely to be stagflationary. 
Thus, our analysis shows, as argued less formally by various observers, that the effectiveness monetary policy may indeed be limited in an environment where excess liquidity in the financial system prevails. In addition, however, it shows that it could actually be much worse - monetary policy could undermine macroeconomic stability by leading to higher inflation and exacerbating contractionary effects on output.

The analysis presented in this paper can be extended in several fruitful directions. First, although increases in the reserve requirement rate were shown to be an effective monetary policy instrument under excess liquidity, the scope for using it may be limited if reserves held at the central bank must be remunerated - even at below-market interest rates. In addition, if the increase in liquidity is due to cyclical factors (such as large increases in capital inflows, for instance), the possible adverse long-term effect of higher required reserve ratios on financial intermediation may create dynamic tradeoffs and further constraint the use of these ratios as instruments of short-term macroeconomic management.

Second, relaxing credit standards to stimulate the demand for loans may also end up lowering the quality of banks' portfolios - thereby making them more vulnerable to default. In that sense, excess liquidity can make the financial system more prone to crisis. An important issue therefore is to analyze what policies, in a second-best environment, can effectively mitigate increased vulnerability. This may offer a different perspective on the role of reserve requirements. Third, a broader menu of collateralizable assets in the economy could be considered, to better account for possible portfolio shifts induced by excess liquidity. As noted earlier, excess liquidity may push banks toward riskier uses of deposits - not only lending to firms (as discussed earlier), but also investment in assets whose collateral value may be highly 
volatile, such as real estate. Greater exposure to risk could weaken banks' balance sheets and increase their vulnerability in a downturn.

At the same time, it is important to expand empirical research by testing for a broader group of countries whether there is evidence that excess liquidity leads indeed to asymmetric bank pricing behavior. Specifically, it is crucial to establish whether the speed of adjustment in deposit rates is significantly different depending on whether excess liquid reserves are above or lower an estimated equilibrium (desired) value. As noted earlier, we are aware of only one study, for Morocco, that explicitly supports this conclusion (Lebedenski (2007)). The error-correction approach used by Scholnick (1996) and Sander and Kleimeier (2000) could usefully be adapted for that purpose. Such studies are essential for strengthening our understanding of how asymmetric bank pricing behavior affects the monetary transmission mechanism. 


\section{References}

Agénor, Pierre-Richard, Joshua Aizenman, and Alexander Hoffmaister, "The Credit Crunch in East Asia: What can Bank Excess Liquid Assets Tell us?," Journal of International Money and Finance, 23 (February 2004), 27-49.

Agénor, Pierre-Richard, and Karim El Aynaoui, "Le mécanisme de transmission de la politique monétaire au Maroc : Un cadre analytique," unpublished, Bank Al Maghrib (May 2007).

Agénor, Pierre-Richard, and Peter Montiel, "Credit Market Imperfections and the Monetary Transmission Mechanism. Part I: Fixed Exchange Rates," Working Paper No. 76, Centre for Growth and Business Cycle Research, University of Manchester (October 2006).

_ _ "Credit Market Imperfections and the Monetary Transmission Mechanism. Part II: Flexible Exchange Rates," Working Paper No. 86, Centre for Growth and Business Cycle Research, University of Manchester (January 2007).

_ - "Monetary Policy Analysis in a Small Open Credit-Based Economy," Open Economies Review, 19 (September 2008a), 423-55.

—, Development Macroeconomics, 3rd ed., Princeton University Press (Princeton, NJ: 2008b).

Bernanke, Ben S., and Mark Gertler, "Agency Costs, Net Worth and Business Fluctuations," American Economic Review, 79 (March 1989), 14-31.

Bester, Helmut, "The Role of Collateral in a Model of Debt Renegotiation," Journal of Money, Credit, and Banking, 26 (February 1994), 72-86.

Boot, Arnoud W. A., Anjan V. Thakor, and Gregory F. Udell, "Secured Lending and Default Risk: Equilibrium Analysis, Policy Implications and Empirical Results," Economic Journal, 101 (May 1991), 458-72.

Castelnuovo, Efrem, and Paolo Surico, "The Price Puzzle: Fact or Artefact?" Working Paper No. 288, Bank of England (January 2006).

Chong, Beng Soon, Ming-Hua Liu, and Keshab Shrestha, "Monetary Transmission via the Administered Interest Rate Channel," Journal of Banking and Finance, 30 (May 2006), 1467-84.

Corvoisier, Sandrine, and Reint Gropp, "Bank Concentration and Retail Interest Rates," Journal of Banking and Finance, 26 (November 2002), 2155-89.

De Bondt, Gabe, "Retail Bank Interest Rate Pass-through: New Evidence at the Euro Area Level," Working Paper No. 136, European Central Bank (April 2002).

Freixas, Xavier, and Jean-Charles Rochet, Microeconomics of Banking, MIT Press (Cambridge, Mass.: 1997). 
Gaiotti, Eugenio, and Alessandro Secchi, "Is There a Cost Channel of Monetary Policy Transmission? An Investigation into the Pricing Behavior of 2,000 Firms," Journal of Money, Credit, and Banking, 38 (December 2006), 201337.

Gertler, Mark, Simon Gilchrist, and Fabio M. Natalucci, "External Constraints on Monetary Policy and the Financial Accelerator," Journal of Money, Credit and Banking 39 (March 2007), 295-330.

Gropp, Reint, Christoffer K. Sorensen, and Jung-Duk Lichtenberger, "The Dynamics of Bank Spreads and Financial Structure," Working Paper No. 714, European Central Bank (January 2007).

Khemraj, Tarron, "Why do Banks Demand Excess Liquidity? Evidence from Guyana," MPRA Paper No. 4721, University of Munich (June 2007).

Lebedenski, Lara, "Excess Liquidity and Monetary Policy under Fixed Exchange Rates: A Theoretical an Empirical Investigation," unpublished, University of Manchester (October 2007).

Mohanti, M. S., Gert Schnabel, et Pablo Garcia-Lima, "Banks and Aggregate Credit: What is New?," in The Banking System in Emergin Economies: How much Progress has been Made?, BIS Papers No. 28, Bank for International Settlements (Basle: August 2006).

Ravenna, Federico and Carl E. Walsh, "Optimal Monetary Policy with the Cost Channel," Journal of Monetary Economics, 53 (March 2006), 199-216.

Sander, Harald, and Stephanie Kleimeier, "Asymmetric Adjustment of Commercial Bank Interest Rates in the Euro Area: Implications for Monetary Policy," unpublished (March 2000).

Saxegaard, Magnus, "Excess Liquidity and Effectiveness of Monetary Policy: Evidence from Sub-Saharan Africa," Working Paper No. 06/115, International Monetary Fund (May 2006).

Scholnick, B., "Asymmetric Adjustment of Commercial Bank Interest Rates: Evidence from Malaysia and Singapore," Journal of International Money and Finance, 15 (June 1996), 485-96.

Taylor, Lance, Structuralist Macroeconomics, Basic Books (New York: 1983). van Wijnbergen, Sweder, "Stagflationary Effects of Monetary Stabilization Policies," Journal of Development Economics, 10 (April 1982), 133-69. 
Figure 1

Macroeconomic Equilibrium

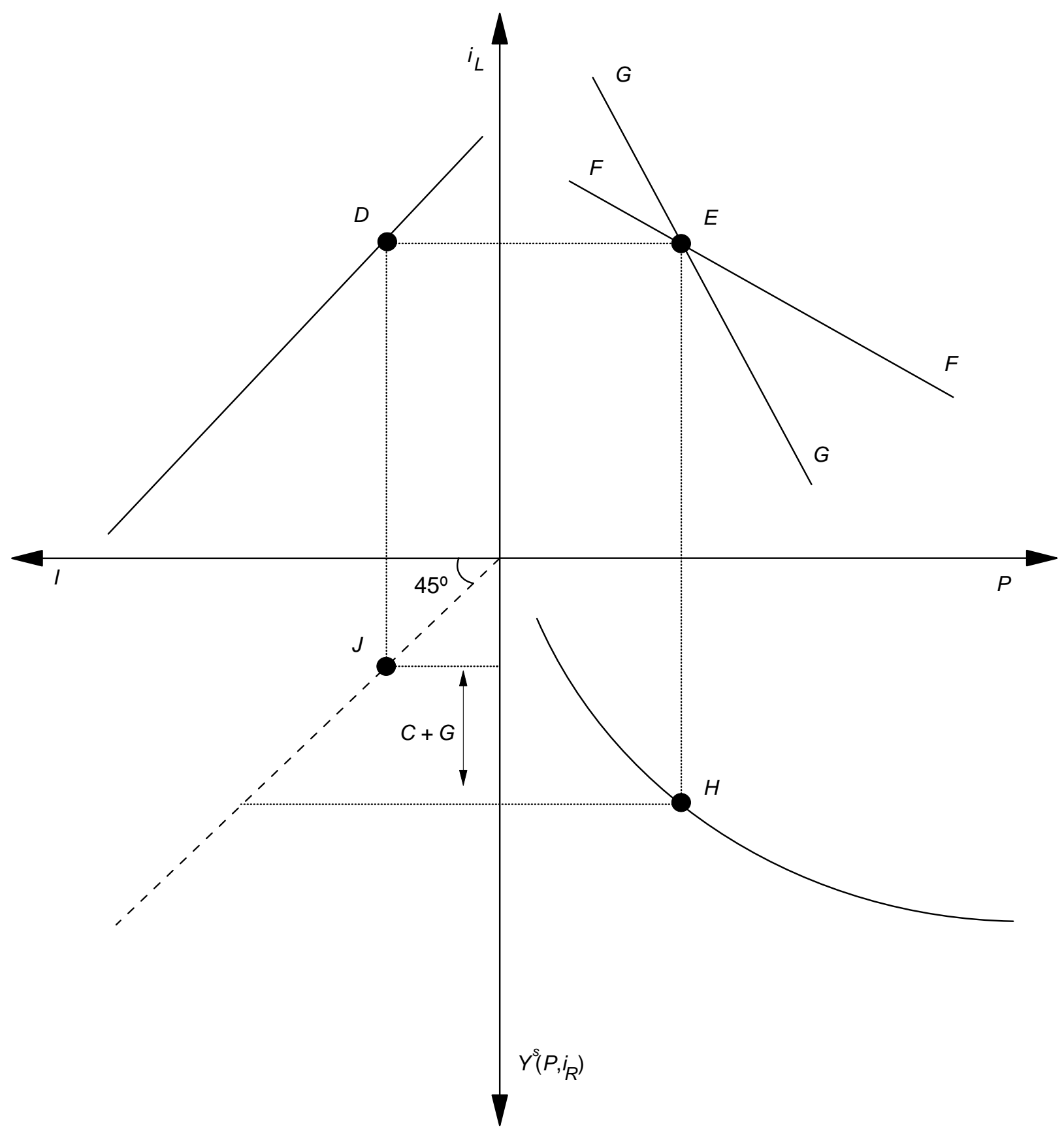


Figure 2

Increase in the Required Reserve Ratio

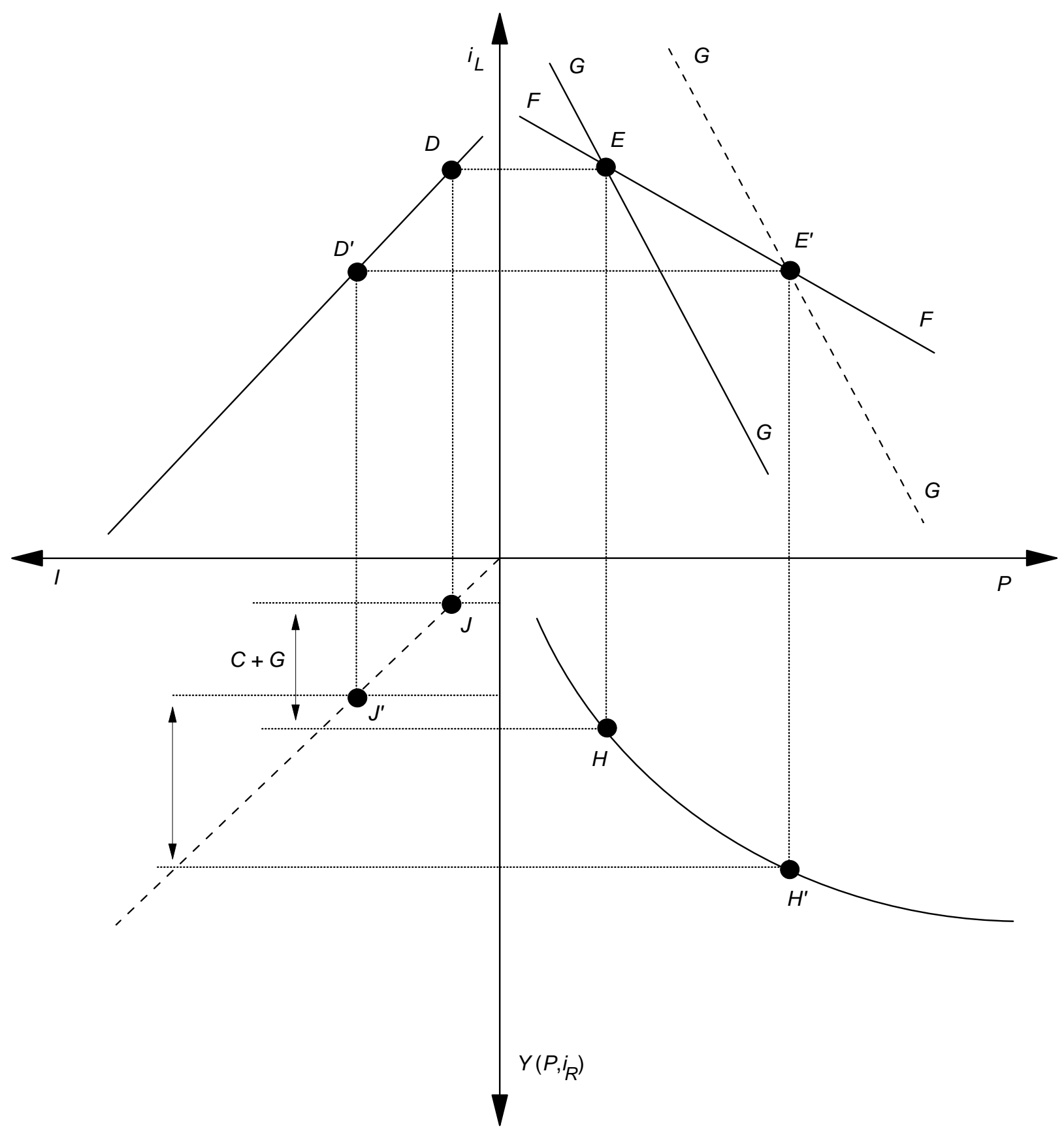


Figure 3

Increase in the Refinance Rate

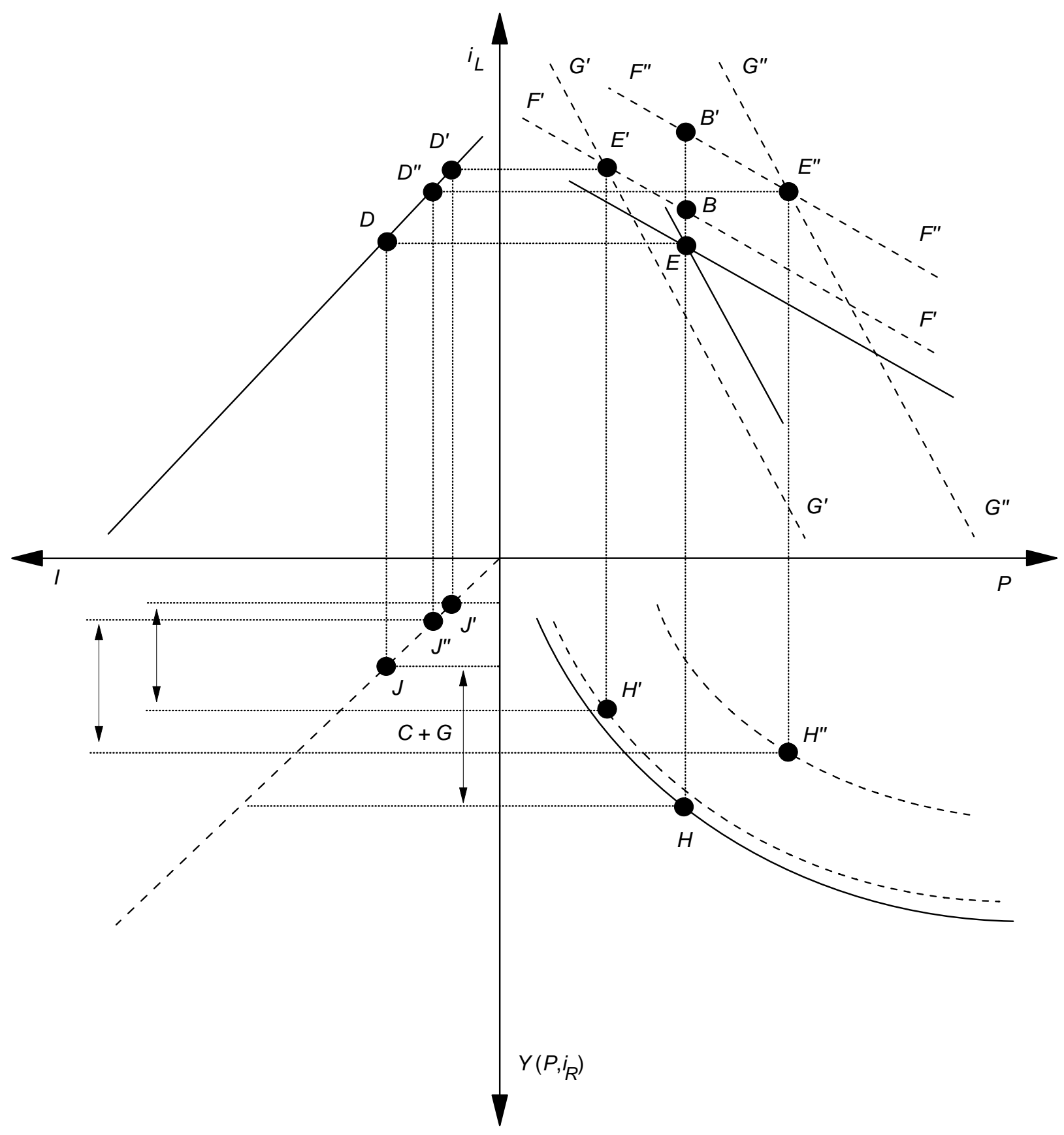

